ББК 65.5

\title{
МОДЕРНИЗАЦИОННЫЙ КОУЧИНГ В СИСТЕМЕ ОБРАЗОВАНИЯ (ПОВЫШЕНИЕ КОМПЕТЕНЦИЙ ПЕРСОНАЛА)
}

\author{
А.Л.ПАСТУХОВ
}

Доцент, к.филос.н., доцент кафедры МТСС ФГБОУ ВО «СПбГЭУ»

Санкт-Петербург, Россия

Статья подготовлена в рамках реализащии проекта 2.2.5 «Проведение научных исследований в сфере потребительских, таможенных и криминалистических услуг населению в рамках научно-образовательного иентра «Технологии товароведческой,таможенной $и$ криминалистической экспертизы» Программы стратегического развития ФГБОУ ВПО «СПбГЭУ» на 2014-2016 годы.

Аннотация

Статья посвящена модернизачии профессионального образования, управлению знаниями, коучингу и технологиям повышения компетенций персонала.

В ней представлены направления модернизации высшего профессионального образования.

Ключевые слова: Образование, управление знаниями, модернизационный коучинг, компетенции персонала.

\section{Summary}

This article is modernization of the higher education system, knowledge management, coacing, technologies improve staff competence.

It presents conditions direction of modernization of the higher education.

Keywords: Education, modernization coacing, staff competence.

\section{ВВЕДЕНИЕ}

Система образования в России развивается более 200 лет. За это время она прошла становление, формирование отечественной педагогической парадигмы и модели управления на основе синтеза германской и французской образовательных систем, создание научных школ в ведущих университетах страны.

В период развития СССР система образования прошла стадию модернизации и интеграции с общей системой экономико-социального управления, направленную на максимальное удовлетворение потребности экономики страны в высококвалифицированных рабочих и инженерах.

В это же время были сформированы и получили мировое признание научные школы в таких областях как ракетостроение, самолетостроение, металлобработка, математика, физика и др. 
Однако, в последнее время, в условиях интеграции России в мировое образовательное пространство и мировой рынок труда, в процессе управления образованием необходимо учитывать и новые мировые тенденции.

В настоящее время имеется значительное число научных исследований, посвященных истории высшего профессионального образования, истории развития университетов, управлению образованием, управлению знаниями, экономике знаний и управлению интеллектуальными ресурсами.

Значительный вклад в исследование развития современной экономики знаний управления интеллектуальным и социальным капиталом внесли Дж. Бекаттини, П. Бурдьё, Дж. Джуран, П.Дракер, М.Маклюэн, А.Маршалл, Й.Масуда, Д.Мэй, Э.Тоффлер, Дж.Гэлбрайт, М.Портер, Т.Стюарт, А. Фейгенбаум, Ф.Хайек и др.

Вопросы управления образованием и развития системы высшего профессионального образования рассмотрены в трудах Г.В. Атаманчук, В.Г. Афанасьева, И.Л. Бачило, Т.И. Березиной, И.В. Волковысского, В.Д. Граждан, А.И. Демидова, Дроздова Г.Д., В.Г. Кинелева, И.О. Котляровой, А.Г. Кузнецова, П.Н. Лебедева, В.В. Лобанова, Б.В. Лытова, А.В. Оболонского, Д.В. Обухова, Г.В. Осипова, Л.П. Погребняк, А.А. Савельева, В.А. Садовничего, С.Б. Суровова, Ю.Г. Татура, В.Д. Шадрикова, Шамовой Т.И., Н.И. Шевченко, Г.К. Шестакова, В.Н. Ярской, Е.Р. Ярской-Смирновой и др.

Теоретические и методические аспекты применения управления знаниями (менеджмент знаний) в образовании представлены в научных, методических трудах и опубликованных результатах исследований Е.Ю. Игнатьевой, А.А. Кузьминой А.А., Т. Нодайна, Л. Петридес, Д.Кидуэлл, К. Вандер Линд, С. Джонсон и др.

Однако, в настоящее время, имеется недостаточно научных работ и аналитических исследований, посвященных внедрению в системе образования новых образовательных технологий: коучинга и применения системы управления знаниями для повышения компетенций персонала.

\section{РЕЗУЛЬТАТЫ И ИХ ОБСУЖДЕНИЕ}

Система управления знаниями является, по нашему мнению, важнейшим элементом и технологией развития современной системы образования, образовательной технологией и компонентом формирования не только профессиональных, но и личностных компетенций (метакомпетенций), необходимых для повышения производительности труда и улучшения корпоративной системы организации.

Так, еще в середине XX века Питер Дракер указывает на рост значимости работников интеллектуального труда и результатов их деятельности в экономике. Фридрих Август фон Хайек подчеркивает роль личностного знания как фактора развития экономических и социальных процессов. Очевидно, что в условиях формирующейся современной информационной экономики применение системы управления знаниями является необходимым условием формирования 
научно-социального сообщества [1], которое бы позволило развивать интеллектуальный капитал страны и расширять коллективную базу знаний.

В управлении образованием система управления знаниями может успешно применяться в следующих направлениях:

1. формирование организационных баз данных и знаний образовательного учреждения, университетского комплекса или образовательного сообщества;

2. применение технологий управления знаниями для повышения компетенций персонала образовательного учреждения, университетского комплекса или образовательного сообщества;

3. формирование информационной прозрачности управления образовательными учреждениями;

4. расширение и систематизация баз данных и знаний образовательного учреждения, университетского комплекса или образовательного сообщества в области научной деятельности;

5. разработка «дорожной карты» внедрения результатов научных исследований и опытно-конструкторских работ в практику, учебный процесс и производство.

6. В управлении учебным процессом система управления знаниями позволяет:

7. обеспечить научную методическую основу применения активных и интерактивных методов обучения;

8. создавать портфолио обучающихся на всех этапах учебного процесса как результат освоения определенных знаний, умений и навыков;

9. максимально конструктивно реализовать потенциал взаимодействия «ученикнаставник» в учебном процессе;

10. повысить качество коммуникативных компетенций обучающихся;

11. шире использовать современные образовательные технологии [2], [3].

Управление знаниями позволяет учитывать в учебном процессе и его организации изменение экономико-социо-ноосферной компоненты общества (технико-технологического уклада, развития НТП, внедрения новых технологий, социальной и половозрастной структуры общества, изменения личностных и социальных потребностей и т. д.) [4].

При этом следует отметить, что формирование знания, по нашему мнению, происходит в результате синтеза с уже имеющейся в сознании информацией и обретения характеристик, позволяющих впоследствии менять содержание и структуру знания в соответствии с особенностями мировосприятия и мышления человека в зависимости от изменения внешней среды. Это, в свою очередь, позволяет встраивать знание в реальную динамичную картину мира человека в каждый момент времени, выявляя постоянные взаимосвязи с новой реальностью.

Соответственно, по нашему мнению, важным отличием знания от информации является то, что информация как феномен неизменна, как система - замкнута, отражает лишь какое-то явление прошлого и теряет свою ценность со временем, не имея устойчивых связей с настоящим и тем более - будущим. Знание, являясь открытой, динамически меняющейся саморазвивающейся 
системой, позволяет не только идентифицировать, анализировать и синтезировать новую информацию, формируя новое знание, но и по своей сущности отражает процессный характер бытия.

По своей форме знания могут быть выражены (формализованы) в виде слова, факта, примера, правила, гипотезы или модели, которые способствуют пониманию определенного трудового, организационного или коммерческого процесса и могут передаваться от одного сотрудника организации другому или группе работников организации в рамках корпоративного взаимодействия. Соответственно, управление знаниями предполагает доступ работников организации к практическому опыту, знаниям и экспертным данным, которые формируют условия, способствующие совершенствованию деятельности организации и стимулирующие инновации, а также позволяющие более качественно определять цели организации и осуществлять планирование. Поэтому, одной из функций знаний в системе управления знаниями является расширение возможностей целеполагания. Этот вид знания, по нашему мнению, можно классифицировать как формальное или фундаментальное [5].

Одной из технологий, основанных на управлении знаниями, которая может применяться в образовании, является коучинг.

Коучинг - инструмент личностного и профессионального развития, формирование которого началось в 70-х годах 20 века. Основой коучинга является сочетание опыта наставничества, результатов наилучшей практики подготовки спортсменов (технологии тренерской работы), применения на практике методов позитивной, когнитивной и организационной психологии, философские и культурологические представления об осознанной жизни и возможностях постоянного и целенаправленного развития человека.

Как и менеджмент качества, коучинг направлен на достижение постоянного улучшения той сферы деятельности и жизни человека, в которой он применяется: образование, управление организацией или определенными организационными процессами, мотивация и поведение человека, самоорганизация; профессиональные, когнитивные, личностные и мета-компетенции.

Как образовательная модель, коучинг представляет собой метод, сочетающий элементы беседы, консалтинга и тренинга, но отличается от них тем, что коуч не даёт советов и жёстких рекомендаций, а ищет решения совместно с клиентом.

Мировоззренческой особенностью коучинга является то, что работа с коучем предполагает достижение определённой цели человека, новых, позитивно сформулированных результатов в жизни и работе.

В деятельностно-психологическом контексте, коучинг — это искусство изменения сознания, отношения к миру человека, которое облегчает движение человека к желаемым целям, так, чтобы оно приносило ему и окружающим удовлетворение.

В коммуникационном аспекте применения коучинг предполагает, в отличие от консалтинга, длительные отношения, которые помогают людям получить значительные результаты в их жизни 
(карьере, бизнесе, политике и социуме). Посредством коучинга обучающиеся расширяют область познания, повышают эффективность и качество своей жизни.

С социальной точки зрения, коучинг - это система социального взаимодействия для реализации совместного социального, личностного и творческого потенциала участников процесса развития с целью получения максимально возможного эффективного результата.

В настоящее время существуют различные виды коучинга и определения данного вида профессиональной и социальной деятельности. Например, Тимоти Голви рассматривает коучинг как искусство создания (с помощью беседы и поведения) среды, которая облегчает движение человека к желаемым целям, так, чтобы оно приносило удовлетворение. Ряд других авторов относят коучинг к искусству содействования повышению результативности, обучению и развитию другого человека.

Среди направлений коучинга можно выделить: поведенческий коучинг, когнитивный поведенческий коучинг, НЛП-коучинг, трансперсональный коучинг, интегративный коучинг, межкультурный коучинг, антистрессовый коучинг.

Карьерный коучинг предполагает определение цели и задач развития социальной (профессиональной) карьеры человека, определение его талантов, способностей, достоинств и недостатков (компетенций), в том числе, имеющих формализованное подтверждение (дипломы, сертификаты, портфолио, рекомендации, публикации и т.д.) с оценкой реального социального и профессионального уровня человека, выстраивание путей достижения цели (SWOT-анализ, создание дорожной карты реализации достижений) и достижение цели.

Бизнес-коучинг предполагает определение цели и задач развития организации или бизнеспроекта (с четкой системой критериев и показателей предполагающих их достижение в определенном временном интервале), определение их сильных, слабых сторон и возможностей (SWOT-анализ) с оценкой текущего уровня развития и реализации (оценка бизнеса и потенциала роста), выстраивание путей достижения цели (расширенный SWOT-анализ, матрица BCG, подготовка бизнес-плана или плана реализации проекта, разработка стратегического плана организации, управления ресурсами и маркетингом, системы управления рисками и знаниями) и достижение цели.

Модернизационный коучинг - это коучинг применяющийся в условиях изменяющейся внешней среды и сознания, как клиента, так и самого коуча, а также соответственно целей и задач в процессе движения к цели, что предполагает фомирование определенной жизненной (бизнес) стратегии.

Концепция модернизационного коучинга постулирует, что не бывает единственно правильного метода достижения цели. Всегда есть несколько путей, каждый из которых имеет свои достоинства и недостатки. И путь достижения цели может динамически меняться «подстраиваясь» под изменения внешней среды и сознания человека. 
Важной основой модернизационного коучинга является применение системы управления знаниями, как в теоретическом аспекте, так и при проведении тренингов, а также глубинных интервью в процессе коуч-сессий [6], [7], [8].

Применение технологий управления знаниями и методов дистанционного обучения позволяет эффективно использовать модернизационный коучинг в образовательном процессе, как в университетских комплексах, так и в коммерческих организациях [9].

В настоящее время в рамках развития модернизационного коучинга в СПбГУСЭ разработаны образовательные курсы повышения квалификации и программа профессиональной переподготовки по коучингу в рамках проекта 1.2.3. «Создание на базе федерального инновационного центра сетевой структуры дополнительного профессионального образования СПбГУСЭ «Олимпийское наследие»» для предпринимателей, молодых-участников бизнесинкубатора СПбГУСЭ, руководителей подразделений по управлению персоналом организаций, научно-педагогических работников с целью формирования компетенций предназначенных для использования в практической деятельности при создании бизнеса, повышении эффективности бизнеса, а также эффективности образовательной деятельности.

В разработке этих программ приняли участие: Ir. Ruud Koopman - senior lecturer entrepreneurship University of Applied Scences Saxion (Netherlands) и Солодовников Сергей Юрьевич - д.э.н., профессор, заведующий кафедрой «Экономика и право» Белорусского национального технического университета (Республика Беларусь).

Развитие модернизационного коучинга, по нашему мнению, может расширить вариативность развития коучинга в России, что, с учетом динамической интеграции страны в мировое образовательное и бизнес-сообщество, будет способствовать и развитию страны в целом с помощью увеличения социального капитала страны.

Применение модернизационного коучинга позволит более эффективно использовать социальный капитал, что является необходимым условием эффективного использования трудовых отношений [10] и обеспечивает условия для формирования необходимых компетенций на качественно ином уровне не только при подготовке будущих специалистов народного хозяйства в системе среднего и высшего профессионального образования, но и в системе управления персоналом коммерческих организаций, так как обучение студентов образовательных учреждений технологиям коучинга позволит интенсифицировать его применение акторами экономических отношений. Более того, это будет способствовать улучшению корпоративной культуры не только образовательных учреждений, но и коммерческих организаций, в которых будут работать выпускники образовательных учреждений, что является важным фактором повышения ее конкурентоспособности [11], [12].

Использование в модернизационном коучинге определенных технологий управления знаниями с помощью интернет-технологий способно сформировать потребность у интеллектуальных работников организаций постоянного поиска новой информации, необходимой для улучшения труда, повышения его эффективности и качества трудового (социального) ресурса. 


\section{ВЫВОДЫ}

Таким образом, в развитии системы образования России и Европы XXI века можно выявить следующие закономерности и тенденции, характерные и важные для современного высшего профессионального образования в России, как с точки зрения качества ее институционального развития, так и с точки зрения ее экономической и социальной эффективности.

- Реформа образования, которая обусловлена изменением социально-экономических отношений в стране и мире, потребностью общества в определенных знаниях и умениях, а государства - в изменении качества трудовых ресурсов.

- Научное, научно-техническое и экономическое отставание России от европейских государств, что предполагает необходимость интенсификации развития экономики страны и национальной культуры, а также достижение лучших мировых образовательных стандартов.

- В России внедряются модели образовательных систем или их элементы, созданные в Европе и адаптированные к социально-экономическим условиям государства.

- Повышению качества высшего образования в России способствует усиление внедрения в образование современных образовательных технологий, модеринизационного коучинга и управления знаниями.

- Модель образования с использованием индивидуальных траекторий обучения предполагает учет в процессе обучения индивидуальных способностей обучающихся в контексте расширения временных рамок образовательного процесса, что обеспечивается применением модернизационного коучинга.

Поэтому, в целях повышения эффективности системы образования, качества подготовки профессиональных кадров для современной экономики необходимо:

- выявление моделей образовательных систем и их элементов, наиболее способных повысить экономическую эффективность системы образования и обеспечение возможностей применения системы управления знаниями как в управлении образованием, так и в образовательном процессе;

- использование исторического опыта развития образования в России и Европе в условиях социально-экономических реформ и применение модернизационого коучинга, объединяющего как передовые образовательные технологи, так и традиционны национальный опыт наставничества;

- создание экономико-математических моделей и баз знаний по управлению высшим образованием, позволяющих моделировать и прогнозировать результаты реформы образования и ее влияния на национальную экономику. 


\section{ЛИТЕРАТУРА}

1. Солодовников, С.Ю. Социально-экономические условия перехода республики Беларусь к постиндустриальному обществу / Известия Самарского научного центра Российской академии наук. Т.9. № 2., 2007.-С.443-448

2. Пастухов, А.Л. Управление знаниями: монография / А.Л.Пастухов. - СПб.: Изд-во СПбГУСЭ, 2011. - 163 с. - С. $140-160$.

3. Пастухов, А.Л. Модель формирования университетского комплекса на основе кластерного подхода // Экономика и управление № 8 (58)., СПб.: СПбАУиЭ. - 2010.- С.96-101

4. Солодовников, С.Ю. Гносеологические трудности при изучении классов в постиндустриальном обществе // Социологический альманах. 2012. №3.- С. 74-91.

5. Пастухов, А.Л. Управление знаниями: монография / А.Л.Пастухов. - СПб.: Изд-во СПбГУСЭ, 2011. - 163 с. - С. 125-135.

6. Пастухов, А.Л. Управление знаниями: монография / А.Л.Пастухов. - СПб.: Изд-во СПбГУСЭ, 2011.-163 с. - С. 15.

7. Пастухов, А.Л. Управление образованием в условиях модернизации экономики: монография / А.Л.Пастухов. - СПб.: Изд-во СПбГУСЭ, 2012.

8. Пастухов А.Л.Коучинг и его развитие в России /Проблемы развития коучинга в России // сборник материалов круглого стола с международным участием, 4 октября 2013 года // Под ред. д.э.н., проф. Дроздова Г.Д., к.ф.-м.н., доц. Угольниковой О.Д. - СПб.: Изд-во СПбГУСЭ, 2013. - С. $13-17$.

9. Пастухов, А.Л. Проблемы и перспективы развития системы управления знаниями в университетском комплексе // Журнал правовых и экономических исследований. № 3, Гатчина: АОУ ВПО ГИЭФПиТ - 2010.- С.78-81.

10. Солодовников, С.Ю. Политико-экономическое исследование сущности социального капитала // Экономика и банки 2010. № 1. С. 54-59.

11. Дроздов, Г..Д. Организационная культура как институциональный фактор развития предприятий сферы услуг / Г.Д. Дроздов, В.Е.Мелехова. Теория и практика сервиса: экономика, социальная сфера, технологии. 2012. № 1 (11).-С. 123-127

12. Дроздов, Г.Д. Интегрированная информационная система университетского комплекса / Г.Д.Дроздов, С.А.Бражников; М-вообразования и науки Российской Федерации, СанктПетербургский государственный университет сервиса и экономики. Санкт-Петербург, 2010. - 163c. - C. 20-35. 